\title{
Esej o rozstaniu. Pamięci Cezarego Wodzińskiego
}

DOI $10.35757 /$ CIV.2016.19.14

\section{rozstanie}

Czym jest rozstanie? Roz-stanie. Wsłuchuję się. Wyraz ten składa się $z$ dwóch części. Brzmi jesiennie: słychać tu oddalenie się, utratę. Roz-... stanie. By go lepiej usłyszeć, staję na nogach, chociaż rozstać się można również, siedząc. Chyba nie o stanie $\mathrm{w}$ rozstaniu chodzi. Kiedy słyszę ten wyraz, uwage moja zrazu zwraca rdzeń -stanie; prefiks roz- wydaje się jedynie dodatkiem, niejako zapowiedzia tego, co ma nastapić po nim: roz-... stanie. Po zastanowieniu się zaczynam w to wattpić. Co, jeżeli w rozstaniu najistotniejsze jest właśnie roz-?

Jakie znaczenie ma prefiks roz-? Słyszany osobno ma barwę ostrą. Rozcięcie, rozprucie, nóż. W zespoleniu ze staniem (się) ostra nie jest. Rozstanie, rozstawanie, rozstawianie, ale również rozdroże, rozstrzygnięcie, rozpacz - jakież to różne słowa. Wszystkie łączy roz-.

„Roz-, zawsze podział jakiś znaczy”, czytam u Lindego'. Zdanie godne namysłu. Rozdzielić można tylko to, co jest uprzednio

Julia Marczyńska - doktor nauk humanistycznych w zakresie filozofii. Absolwentka Szkoły Nauk Społecznych przy IFiS PAN, gdzie w roku 2010 obroniła doktorat z filozofii języka. W ramach wymiany akademickiej spędziła rok w Stanach Zjednoczonych. Wielokrotna stypendystka, m.in. programu The International Higher Education Support Program (HESP), fundacji „Smołoskyp” (Ukraina) oraz Fundacji im. Włodzimierza Wiernadskiego (Rosja). Autorka artykułów naukowych, tłumaczka.

1 X.O. Kopczyński, Układ grammatyki dla szkół narodowych $z$ dzieła już skończonego wyciagniony, drukarnia Michała Grölla, Warszawa 1785, p. 261, cyt. za S.B. Linde, Słownik języka polskiego, Drukarnia Zakładu Ossolińskich, Lwów 1859, T.V, s. 75. 
połączone lub jest jednym od początku. To zastanawiajace, a zarazem nierozstrzygalne, gdzie bowiem mielibyśmy szukać początku? Gdzie szukać początku przyjaźni, wspólnej podróży po krainie, „co zwie się myśleniem"2? Pierwszy wykład, którego wysłuchałam, pierwsza wymiana zdań? Stało się jednak tak, że ten pierwszy wykład zaprowadził mnie tam, gdzie od zawsze byłam (od początku?) i gdzie ze zdziwieniem odkryłam siebie jako próbująca myśleć. Czy ja próbująca myśleć zaprowadzona przez mówcę tam przyszłam, czy byłam tam $z$ nim od poczatku? Tego nie wiem. Wiem, że nie byłam tam (tutaj) sama, że miałam Przewodnika. Stanęłam przy nim, przystałam z nim, słuchanie zaś tego, co mówi, stało się moja przystanią. Przeciwieństwem rozstania nie jest bowiem spotkanie, tylko przystanie, przystań. W tym przypadku była to przystań żeglarska.

„Nie widzę, jakoby się to rozstać mogło, co się już raz stało"3, czytam dalej u Lindego. W tym zdaniu czasownik rozstać się występuje jako przeciwieństwo stać się w sensie nieodwracalności. Tego, co zostało rozcięte, roztłuczone lub rozstrzygnięte, nie da się zciąć, uttuc lub zastrzygnać z powrotem. Rozpięte da się $z$ powrotem zapiać, ale takiego rodzaju czasowniki zdecydowanie sa w mniejszości. Roz- przeważnie ma znaczenie nieodwracalności. Czy rozstanie również jest nieodwracalne? Czy może, tak jak $\mathrm{w}$ przywołanym zdaniu, nieodwracalne jest raczej stanie się?

To, co u-słyszane, nie może zostać roz-słyszane w sensie odwrócenia działania, tego zaś, co zobaczone, nie da się roz-widzieć $z$ powrotem. W ten sam sposób nie może się rozstać to, co się raz już stało. A może raczej to, jak się raz już stało, lub to, kim się raz już stało.

Odpowiednikiem ogólnosłowiańskiego roz- jest łacińskie dis-. Rzeczownik $z$ tym prefiksem spotykamy w cytowanej przez Heideggera wypowiedzi świętego Augustyna na temat czasu: inde mihi visum est, nihil esse aliud tempus quam distentionem; sed cuius

Nawiazanie do rozprawy Heideggera, Co zwie się myśleniem, Warszawa - Wrocław 2000.

3 M. Bielski, Kronika świata, 1564, s. 533, cyt. za S.B. Linde, Słownik języka polskiego, s. 137. 
rei nescio, et mirum si non ipsius animi ${ }^{4}$. Distentio. Wyraz ten został przetłumaczony jako rozciagłość. Dis- nie znaczy tu podziału, chodzi o rozprzestrzenienie i rozszerzenie, objęcie działaniem większej przestrzeni, tak jak $\mathrm{w}$ słowach rozległy, rozpowszechnienie, rozpostarcie.

Dis- w znaczeniu rozciagłości zamiast o podziale mówi o zachowaniu jedności. To, co się rozpostarło i rozciagnęło, rozrosło się i rozłożyło, nie przestało być jednościa, jedynie się powiększyło lub zaczęło zajmować większą przestrzeń.

Rozstanie się jest częścią większego zjawiska, które można byłoby nazwać przebywaniem razem, wspólnym byciem, przystaniem się. Struktura tego zjawiska przedstawia się w sposób następujący:

1. przybycie w pobliże siebie (ruch zbliżajaccy);

2. przebywanie w pobliżu siebie, wspólna wędrówka (ruch w tym samym kierunku);

i wreszcie

3. rozstanie się (ruch oddalający).

$Z$ tych trzech tylko ostatnie stadium ma charakter otwierajacy i darujacy. Rozstanie Platona $z$ Sokratesem dało światu Platona. Stało się tak dlatego, że to trzecie, ciężkie i jakże bolesne stadium stwarza nowa przestrzeń; jak rozłam płyty tektonicznej, tak rozłam wspólnego przystania się młodego adepta filozofii i jego Mistrza stwarza nowa przestrzeń, przestrzeń pomiędzy jednym a drugim, przestrzeń pomiędzy. W języku odpowiednikiem tej przestrzeni jest jego najbardziej pojemna jednostka semantyczna - pauza.

\section{pauza}

Dnia 31 sierpnia 1941 roku odbyło się pewne rozstanie. Doświadczył tego rozstania poeta. W miejscu rozstania zostały trzy

4 „Stąd zdaje mi się, że czas nie jest niczym innym jak rozciagłością. Nie wiem jednak, jakiej rzeczy jest rozciagłościa; a kto wie, czy nie samego umysłu”. Cyt. za M. Heidegger, Bycie i czas, przekład B. Baran, Wydawnictwo Naukowe PWN, Warszawa 2008, s. 535. 
kartki papieru. Na kartkach pismem odręcznym napisano trzy krótkie przesłania do tych, którzy przyjda tam, na miejsce rozstania, po tym, jak się odbędzie. Te krótkie teksty zawierające prośby, jak również wyjaśnienia, dlaczego rozstanie było nieuniknione, adresowane były do tych, którzy - jak się spodziewał ich autor - moga go wysłuchać i te prośby spełnić. Piszacy wiedział natomiast, że jego przesłania najpierw - a może wyłącznie - trafia do rąk pracowników NKWD.

Rozstanie było rozstaniem z życiem, poeta - Marina Cwietajewa ${ }^{5}$.

Zanim się powiesiła na haku w sieniach wiejskiej chaty w Tatarstanie $^{6}$, napisała trzy pośmiertne listy. Do ewakuowanych, do Asiejewych $\mathrm{i}$ do syna. Interesuje mnie ten ostatni. Wydaje mi się, że może on być zapisem rozstania, a co za tym idzie, pomoże mi zrozumieć, czym jest rozstanie.

Czytam listy. W pierwszych dwóch nie czuć pośpiechu, widać natomiast straszliwa trwoge matki o dziecko ${ }^{7}$, które zostaje samo, w czasie wojny, bez środków do życia, w cudzym miejscu, we wrogim mu kraju. W liście do syna czuć pośpiech. Była sama. Zamknęła drzwi do chaty, okno zostawiła otwarte. Powiesiła się $\mathrm{w}$ pomieszczeniu mierzacym dwa metry wysokości, nie zdjąwszy granatowego fartucha. $\mathrm{Na}$ piecu zostawiła usmażona rybę. Miała 48 lat.

Powodów „nie być” Cwietajewa miała pod dostatkiem - w żaden możliwy sposób nie pasowała do radzieckiej Rosji, była żoną białego oficera, jej twórczość uchodziła w tym systemie za bełkot, nie mogła nic wydać, nie miała środków do życia ani przyjaciół. Mąż i córka znajdowali się w areszcie, zanim została ewakuowana,

\footnotetext{
5 Marina Cwietajewa zawsze mówiła o sobie, używając formy męskiej, „poeta”.

6 Dziś w tej drewnianej chacie jest Dom Pamięci Mariny Cwietajewej. Gości zaprowadzani sa do sieni, gdzie - jak i w całym domu - odtworzono atmosferę z sierpnia $1941 \mathrm{r}$. Zwiedzający mogą obejrzeć belkę, w którą wbity był gwóźdź zagięty w kształcie haka. Dokładne miejsce wbicia gwoździa jest nieznane.

7 Syn Cwietajewej Georgij miał wtedy 16 lat.

8 W roku 1940 zapisała w swoim zeszycie: „Nie chcę - umrzeć, chcę - nie być” („Я не хочy - умереть, я хочу - не быть", http://www.tsvetayeva.com/prose/pr_iz_zap_kn7 [dostęp 12 listopada 2016].
} 
nosiła im paczki. Każda $z$ tych okoliczności - a było ich więcej - była dla niej bardzo trudna. Bała się aresztowania, mówiła: „Jeśli przyjda za mna - powieszę się", ale nade wszystko bała się o syna. Jej wszechogarniająca, bezgraniczna, „zwierzęca”10 matczyna miłość nie pozwalała i nigdy nie pozwoliłaby jej przestać dbać o niego.

8 sierpnia 1941 roku Cwietajewa $z$ synem wsiadzie w Moskwie na parowiec i 17 sierpnia stąpi na ziemię Tatarstanu. Zaczynając od dnia swojego przyjazdu, bezskutecznie szuka pracy - praca jest, ale nie dla niej, ma bowiem „zła ankietę”. Nie rezygnuje jednak $z$ walki o zarobek, rozmawia $z$ ludźmi na ulicy, szuka pomocy, szuka nowego pokoju. Jest wyczerpana do granic możliwości, ale świadectwa zebrane przez jej biografów układaja się w jasny obraz - nie ma depresji1 ${ }^{11}$. Warto tu wspomnieć, że była to kobieta, która doskonale wiedziała, czym jest nędza i głód, i była w stanie znieść naprawdę wiele. W roku 1920 udźwignęła śmierć trzyletniej córki Iriny, która zmarła $z$ wycieńczenia $\mathrm{w}$ podmoskiewskim sierocińcu, gdzie matka oddała ja, uwierzywszy obietnicy, że będzie dostawała „ryż i czekoladę”. W domu Cwietajewej panował głód. Starsza córka była chora, matka walczyła o jej życie. Udało się. Wymarzonego syna urodziła pięć lat później. Według licznych świadectw kochała go bez opamiętania. Jednym jedynym wewnętrznym musem, by go zostawić, mogło być przekonanie, że tylko w ten sposób jest w stanie go uchronić.

Daje się to wyczytać $z$ listów do ewakuowanych i do Asiejewych, które są w całości wypełnione prośbami, by dbać o Mura ${ }^{12}$ i pomóc mu w tych czy innych sprawach. Co do siebie, miała jedyna prośbę:

\footnotetext{
9 Ирма Кудрова, Гибель Марины Цветаевой, Издательство "Независимая Газета", Москва, 1995, http://tsvetaeva.narod.ru/WIN/kudrova/kudrG06.html [dostęp 16 września 2016].

${ }_{10}$ Дмитрий Сеземан, Марина Цветаева, Георгий Эфрон и возвращение в СCCP (Dmitrij Sezeman, Marina Cwietajewa, Georgij Efron i powrót do ZSRR), cz. 1, Radio Swoboda, 28 sierpnia 2006, http://www.svoboda.org/a/262693.html [dostęp 23 września 2016].

${ }^{11}$ Ирма Кудрова, Гибель Марины Цветаевой, Издательство "Независимая Газета", Москва, 1995, http://tsvetaeva.narod.ru/WIN/kudrova/kudrG06.html [dostęp 16 września 2016]. ${ }^{12}$ Syna Cwietajewej członkowie rodziny i przyjaciele nazywali Murem.
} 
"Nie pochowajcie mnie żywą! Dobrze sprawdźcie"13. Dlaczego jednak jej odejście miałoby go uchronić? Badacze życia Cwietajewej zebrali świadectwa, pokazujace, że po przybyciu do Ełabugi mogła być wzywana do miejscowego oddziału NKWD, gdzie zaproponowano by jej donosicielstwo na kolegów literatów, szantażowano zaś tym, co wyłącnie miała do stracenia - synem.

List do syna jest najkrótszy, składa się jedynie $z \quad 42$ słów. Ostatnie zdanie - bez kropki. Były to ostatnie słowa, które ręka Cwietajewej nakreśliła na kartce papieru. Czy w tych słowach odbyło sie jej rozstanie $z$ życiem?

List napisany jest w języku rosyjskim. Podaję go w wersji oryginalnej oraz $\mathrm{w}$ polskim przekładzie.

Мурлыга! Прости меня, но дальше было бы хуже. Я тяжело больна, это уже не я. Передай папе и Але - если увидишь - что мюбима их до посмедней минуты и объясни, что попала в тупик

Murłygo! Wybacz mi. Ale dalej byłoby jeszcze gorzej. Jestem ciężko chora, to już nie jestem ja. Kocham cię do szaleństwa. Zrozum, że ja już dłużej nie mogłam. Powiedz tacie i Ali - jeśli ich zobaczysz - że kochałam ich do ostatniej chwili, i wytłumacz, że wpadłam w ślepy zaułek ${ }^{14}$.

W tekście oryginału sa dwa podkreślenia, mianowicie „jestem ciężko chora” i „znalazłam się w ślepym zaułku”. Wydaje mi się, że jeśli Cwietajewa chciała przekazać coś synowi, wiedząc, że najpierw dostanie to do rak ktoś obcy i wrogi, musiała napisać tak, by, po pierwsze, list w ogóle został przekazany (Mur później musiał się starać o to, by milicja oddała mu list, który chciano zatrzymać jako „materiał śledczy”); po drugie zaś, przekazać to, co było do przekazania, tak by nie odczytał tego obcy człowiek, ale zrozumiał syn.

\footnotetext{
${ }^{13}$ Zgaduję, że tu było podkreślenie. Zdjęcia tego zapisku nie ma, milicja go nie oddała, tekst został przepisany przez syna; na przedrukowanym liście znajdującym się w Domu Pamięci Mariny Cwietajewej te słowa podano kursywa. Zdjęcie przedruku zapisku - strona internetowa rozgłośni radia Echo Moskwy: "Tо nоступь вечности за мнои". К 120-летию со дня рождения Марины Цветаевой, сz. 2, 14 października 2012, http://echo.msk.ru/ programs/time/939956-echo/ [dostęp 12 listopada 2016].

${ }^{14}$ G. Efron, $Z$ dziennika, przekład M. Ochab, „Zeszyty Literackie” 2005, nr 4, s. 56-73.
} 
Napisała, że jest ciężko chora, chociaż - na ile udało mi się zorientować - była zdrowa ${ }^{15}$. Dla mnie jest oczywiste, że odczuwała ogromne przygnębienie, nie była to jednak depresja w sensie utraty chęci życia, ponieważ na kilka dni przed 31 sierpnia Cwietajewa próbowała jeszcze walczyć z losem. Była zdrowa. Dlaczego więc napisała i dlaczego podkreśliła jestem ciężko chora?

Jak Mur miał to odczytać? Jestem ciężko chora - co dla niego miałoby znaczyć to zdanie? Podkreślone wygląda jak to nie jestem ja, co zreszta pojawia się zaraz potem, explicite. Może to też znaczyć dla Ciebie jestem źródłem niebezpieczeństwa, a więc nie tylko nie mogę Ci już w niczym pomóc, staję się dla Ciebie ciężarem. W liście do Asiejewych pisze o Murze „Ja już nic więcej dla niego [zrobić] nie moge i tylko go zaprzepaszczam". W liście do ewakuowanych: "Chcę, by Mur żył i się uczył. Ze mna przepadnie”. Tu też podkreślenie ${ }^{16}$.

Jestem ciężko chora. Dlaczego nie podkreśliła drugiej części tego zdania, mianowicie, to już nie jestem ja? Może dlatego, że decyzja o odejściu była jej własna decyzja, wymuszona przez okoliczności, a jednak podjęta przez nia samą? Drugie podkreślenie wydaje się to potwierdzać: wpadłam w ślepy zaułek. Cwietajewa, tak wyczulona na słowa, nie napisała „nie mam więcej siły”, tylko „znalazłam się w ślepym zaułku”, czyli, że nie ma gdzie dalej iść. W liście do ewakuowanych napisała: „Не вынесла” („Nie zniosłam"). Nie uważam jednak, że ten tekst jest godny zaufania w kwestii powodów, które skłoniły Cwietajewą do jej czynu. Został napisany dla obcych ludzi i miał dostać się - najpierw, jak i docelowo - do rak obcych ludzi, którym należało powiedzieć to, co w tym przypadku chcieliby usłyszeć. Niech myśla, że nie dała rady. "Wpadłam w ślepy zaułek”. Mogłabym iść dalej, ale nie mam gdzie, nie prowadzi stąd żadna droga ani ścieżka, jest tylko ściana i... belka.

${ }^{15}$ Bolały ją nogi, ale według mojego przekonania nie mogło to stać się powodem jej rozstania się $\mathrm{z}$ życiem.

${ }^{16}$ Zgaduję, że to było podkreślenie (zob. przyp. 12). 
Tekst zapisku nosi wszelkie znamiona rozstania. Wybacz mi to po rosyjsku npocmu - czasownik, który jest jedna $z$ form npouaŭ, czyli żegnaj. W rozstaniu chodzi o pożegnanie. „Kocham Cię do szaleństwa" - w rozstaniu chodzi o miłość. Do ostatniej chwili - rozstanie odbywa się w czasie, ma swoja pierwsza i ostatnia chwilę. Ostatnia to po rosyjsku nоследняя, czyli posledniaja, ta, po której zostaje sled (ślad). Rozstanie zostawia ślad. I wreszcie ślepy zaułek. Co najmniej dla jednego $z$ tych, co się przystaja, albo dla ich wspólnej wędrówki.

„Jestem cièżko chora”; "znalazłam sie w ślepym zaułku” - te dwa zdania zaprzeczaja sobie nawzajem, może dlatego oba zostały podkreślone? Jednej $z$ tych okoliczności wystarczyłoby, by wyjaśnić powód, dla którego uczyniła to, co uczyniła. Czy ma znaczenie, gdzie się znalazł ten, kto jest ciężko chory - na rozdrożu czy w ślepym zaułku? Zostanie zabity przez chorobę. Ślepy zaułek może się okazać śmiercionośny tylko dla tego, kto mógłby jeszcze iść, kto ma siłę i ma po co iść dalej. Dlaczego więc podkreśliła te dwie frazy? Jestem ciężko chora miałoby znaczyć:

Mur, to nie ja piszę. Wiesz przecież, że jestem wolna, a ostatnio stało się tak, że być wolna przestałam. Złapano mnie. Nie jestem już wolna, a więc to nie jestem już ja. Przekaż Tacie i Ali, że - dosłownie - wpadłam w sensie złowiono mnie do ślepego zaułku. Po rosyjsku nопала в туnuк, ten sam czasownik występuje w zwrotach wpaść do pułapki (nonacms в ловушкy), zostać złowionym $w$ sieci (nonacmь в сетu), mam Cie (nonarca). A więc nie znalazłam sie, zawędrowałam czy zabładziłam, tylko wpadłam, złapano mnie.

Jak każdy tekst wielkiego poety zapisany proza ten też da się zapisać w formie wiersza. Słychać tu ból, ale i spokój, który daje podjęta i przemyślana decyzja.

Мурцыга!

Прости меня, но дальше было бы хуже.

Я тяжело-больна, это уже не я. 


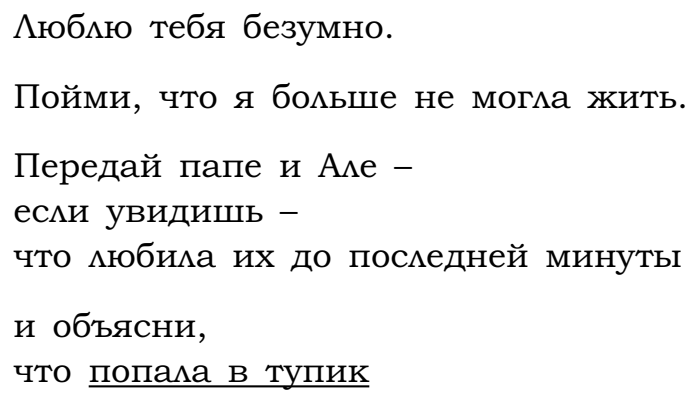

Tekst został przeze mnie zapisany zgodnie $z$ układem pauz. Sa różnej długości, różnią się również - tak jak pauzy w utworze muzycznym - głębokością i brzmieniem. Długość uzależniona jest od tempa czytania, na brzmienie pauzy zaś wpływ ma jej otoczenie: to, co ja poprzedza, oraz to, co następuje po niej. Tekst zawiera siedem krótszych pauz oraz dwie dłuższe. Najbardziej tajemnicza jest jednak pauza dziesiąta, ta, która rozwiera się po ostatniej sylabie ostatniego słowa, a której długość jest nie do obliczenia. Kto wie, być może trwa do dziś. Nie widać tu kropki, nie znaczy to jednak, że jej nie ma. Kropka mogła zostać postawiona wcześniej, zanim powstał ten tekst. Co, jeśli ten list nie jest zapisem rozstania? Co, jeżeli rozstanie odbyło się wcześniej? Rozstanie się z życiem mogło się odbywać stopniowo, w ciagu tygodni i miesięcy po powrocie $z$ emigracji ${ }^{17}$, czego potwierdzenie można znaleźć we wspomnieniach znajomych Cwietajewej i w jej wierszach. Rozstanie $z$ synem mogło się zacząć tegoż dnia rano.

Czy zaczęło się rano, po tym, kiedy widzieli się po raz ostatni? To mogłoby być prawda dla Cwietajewej, ale czy mogłoby być prawda dla Mura? A może dla Mura zaczęło się w momencie, kiedy o wszystkim się dowiedział? Czy w ten sposób możemy mówić o dwóch rozstaniach? $\mathrm{Na}$ pierwszy pogląd było jedno, to, które zaczęło się po tym, kiedy po raz ostatni się widzieli, $z$ tym tylko, że Mur nie wiedział, że to było po raz ostatni, a więc dla niego

${ }_{17}$ Cwietajewa wróciła do ZSRR w czerwcu 1939 r., po 17 latach emigracji. 
to bycie-w-rozstaniu, które zaczęło się po byciu-razem, jeszcze takowym nie było. A może rozstanie odbyło się w czasie pomiędzy, pomiędzy tym momentem, kiedy się widzieli, a tym, kiedy Mur dowiedział się o tym, co się stało w czasie jego nieobecności?

Pytania te - których każdy, kto doznał rozstania, doświadcza niczym wiwisekcji - pokazuja, jak zagadkowym zjawiskiem jest rozstanie. Kiedy się odbywa? Gdzie się odbywa? W przestrzeni pomiędzy? W czasie pomiędzy? Tak mało o rozstaniu wiemy. Ile rozstanie trwa? Kiedy się zaczyna? Czy możemy mówić o chwili rozstania, czy może o procesie rozstawania się? Tylko niektóre cechy tego zjawiska wydaja się być pewne: by rozstanie było możliwe, trzeba dwóch, by zaś się odbyło, wystarczy, by coś uczynił jeden (lub by coś się stało $z$ jednym).

Te dwa rozstania, które przydarzyły się Marinie Cwietajewej 31 sierpnia 1941 roku, różniły się pod wieloma względami. Jedno z nich odbyło się „tu i teraz”, drugie zostało rozłożone w czasie. To drugie rozstanie odbyło się w dwóch aktach. Najpierw ze wspólnej przystani odcumował jeden, później doświadczył tego rozstania drugi.

Rozstanie nie jest czymś, co przychodzi nagle. Jest ono wpisane w przystanie się i jest w nim ciagle obecne, od początku. $\mathrm{W}$ pierwszym spojrzeniu matki na dziecko zawiera się, w formie niewypowiedzianej, jej ostatnie spojrzenie, jak w pierwszej rozmowie przyjaciół - ich ostatnia wymiana zdań. Czy jednak ostatnie koniecznie znaczy tu ostateczne? Może rozstanie to tylko pauza, coś, co wypełnia przestrzeń pomiędzy: pomiędzy jednym a drugim przystaniem się, pomiędzy jednym a drugim byciem blisko siebie?

Syn, o którego Cwietajewa tak się troszczyła w przedśmiertnych zapiskach, zginął dwa lata później, córka zaś, która zrehabilitowano w roku 1955, nigdy nie przebaczyła Asiejewym, którym Cwietajewa zawierzyła ukochanego Mura. Głos ze skierowanej do nich pośmiertnej noty nie został usłyszany. Zapisek adresowany do syna $z$ pewnościa został wysłuchany bardziej uważnie. To właśnie tu miał miejsce ostatni akt trwającego wiele miesięcy 
rozstania. Oprócz słów zostawiła w tym zapisku myślniki, brak kropki i podkreślenia. Te ostatnie wydaja mi się najistotniejsze.

W swoich wierszach składała drabinki $z$ myślników, bawiła się nimi, rozkoszowała i zatracała się w nich. Była blisko języka, także tego pisanego, a najodpowiedniejszy był dla niej układ pionowy. Ostatnim, co napisała, był zapisek do syna i tu znów pojawia się drabinka. Tym razem poprzeczki tej drabinki - to podkreślenia. Czy wspięła się po tej drabince w górę, czy zeszła w dół? Ponieważ w sposób oczywisty dotknęła dna i właśnie tam się znajdowała w czasie pisania tego tekstu, niżej zejść nie byłaby już zdolna. Tyle lat bawiła się drabinkami, by tym razem wstapić na jedna $z$ nich. W chwili gdy stanęła noga na poprzeczce - oderwała się od ziemi, by nigdy już jej nie dotknaćc. Rozstała się między niebem i ziemia, w przestrzeni pomiędzy.

\section{distantia}

Łacińskim odpowiednikiem rozstania jest distantia ${ }^{18}$. Wyraz ten też składa się $z$ prefiksu o znaczeniu rozdzielajacym i rozszerzającym oraz czasownika "stać”. Distantia jest zjawiskiem przestrzennym i to również łączy ja $z$ rozstaniem. W rozstaniu chodzi o odległość, o dystans, za sprawą którego bycie razem rozciaga się, rodzac przestrzeń pomiędzy. Dzięki owej przestrzeni rozstanie się przybiera inna postać niż „rozłączenie się”. Staje się rozciagłością. $\mathrm{W}$ takim rozstaniu przystanie nadal trwa.

\footnotetext{
${ }^{18}$ Wyraz ten wywodzi się od czasownika distāre, czyli stać $w$ odległości [od siebie], gdzie dis- znaczy „osobno”, stare zaś znaczy „stać”. W słowniku etymologicznym napisano o praindoeuropejskim rdzeniu stā-, który można zobaczyć w obu tych wyrazach, http://www. etymonline.com/index.php?term=distance [dostęp 23 września 2016].
} 